\title{
DNAJC3 deficiency induces $\beta$-cell mitochondrial apoptosis and causes syndromic young-onset diabetes
}

\author{
Maria Lytrivi(D)1,2,*, Valérie Senée ${ }^{3, *, \dagger}$, Paraskevi Salpea1,*, Federica Fantuzzi1,*, Anne Philippij ${ }^{3, \dagger}$, \\ Baroj Abdulkarim ${ }^{1}$, Toshiaki Sawatani', Sandra Marín-Cañas', Nathalie Pachera1, Anne Degavre ${ }^{3, \dagger}$, \\ Pratibha Singh', Céline Derbois ${ }^{4}$, Doris Lechner ${ }^{4}$, Laurence Ladrière ${ }^{1}$, Mariana Igoillo-Esteve ${ }^{1}$, \\ Cristina Cosentino ${ }^{1}$, Lorella Marselli, Jean-François Deleuze ${ }^{4}$, Piero Marchetti ${ }^{5}$, Décio L Eizirik ${ }^{1,6}$, \\ Marc Nicolino7, Annabelle Chaussenot ${ }^{8,9}$, Cécile Julier $^{3, \pm}$ and Miriam Cnop ${ }^{1,2, *}$
}

${ }^{1}$ ULB Center for Diabetes Research, Medical Faculty, Université Libre de Bruxelles, Brussels, Belgium, ${ }^{2}$ Division of Endocrinology, Erasmus Hospital, Université Libre de Bruxelles, Brussels, Belgium, ${ }^{3}$ Université de Paris, Faculté de Médecine Paris-Diderot, Inserm U958, Paris, France, ${ }^{4}$ Centre National de Recherche en Génomique Humaine (CNRGH), Institut de Biologie François Jacob, Commissariat à l'Energie Atomique, Université Paris-Saclay, Evry, France, ${ }^{5}$ Department of Clinical and Experimental Medicine, University of Pisa, Pisa, Italy, ${ }^{6}$ Indiana Biosciences Research Institute, Indianapolis, Indiana, USA, ${ }^{7}$ Division of Pediatric Endocrinology, Lyon 1 University, Lyon, France, ${ }^{8}$ IRCAN, UMR CNRS 7284/Inserm U1081/UNS, School of Medicine, Nice Sophia-Antipolis University, Nice, France, and ${ }^{9}$ Department of Medical Genetics, Nice Teaching Hospital, National Centre for Mitochondrial Diseases, Nice, France

*(M Lytrivi, V Senée, P Salpea and F Fantuzzi contributed equally to this work as first authors) ${ }^{\dagger}($ V Senée, A Philippi, A Degavre and C Julier are now at Université de Paris, Institut Cochin, Inserm U1016, Paris, France) ${ }^{\ddagger}$ (C Julier and M Cnop contributed equally as senior authors)

Correspondence should be addressed to C Julier or M Cnop Email cecile.julier@inserm.fr or mcnop@ulb.ac.be

\begin{abstract}
Objective: DNAJC3, also known as P58 $8^{\mathrm{IK}}$, is an Hsp40 family member that interacts with and inhibits PKR-like ER-localized elF2 $\alpha$ kinase (PERK). Dnajc3 deficiency in mice causes pancreatic $\beta$-cell loss and diabetes. Loss-of-function mutations in DNAJC3 cause early-onset diabetes and multisystemic neurodegeneration. The aim of our study was to investigate the genetic cause of early-onset syndromic diabetes in two unrelated patients, and elucidate the mechanisms of $\beta$-cell failure in this syndrome.

Methods: Whole exome sequencing was performed and identified variants were confirmed by Sanger sequencing. DNAJC3 was silenced by RNAi in INS-1E cells, primary rat $\beta$-cells, human islets, and induced pluripotent stem cellderived $\beta$-cells. $\beta$-cell function and apoptosis were assessed, and potential mediators of apoptosis examined. Results: The two patients presented with juvenile-onset diabetes, short stature, hypothyroidism, neurodegeneration, facial dysmorphism, hypoacusis, microcephaly and skeletal bone deformities. They were heterozygous compound and homozygous for novel loss-of-function mutations in DNAJC3. DNAJC3 silencing did not impair insulin content or secretion. Instead, the knockdown induced rat and human $\beta$-cell apoptosis and further sensitized cells to endoplasmic reticulum stress, triggering mitochondrial apoptosis via the pro-apoptototic BCl-2 proteins BIM and PUMA. Conclusions: This report confirms previously described features and expands the clinical spectrum of syndromic DNAJC3 diabetes, one of the five monogenic forms of diabetes pertaining to the PERK pathway of the endoplasmic reticulum stress response. DNAJC3 deficiency may lead to $\beta$-cell loss through BIM- and PUMA-dependent activation of the mitochondrial pathway of apoptosis.
\end{abstract}

European Journal of Endocrinology

(2021) 184, 455-468 


\section{Introduction}

Monogenic forms of diabetes represent 2-4\% of all cases in children and young adults $(1,2)$. Mutations in genes key for pancreatic $\beta$-cell development, maintenance or function provide important insights into molecular pathways underlying diabetes. Studies on monogenic diabetes related to the endoplasmic reticulum (ER) stress response (3) produced compelling evidence for the role of dysregulated ER stress signaling in $\beta$-cell demise in monogenic and multifactorial forms of diabetes (4). In particular, mutations in genes in the PKR-like ER-localized eIF2 $\alpha$ kinase (PERK) branch of the ER stress response (e.g. EIF2AK3, PPP1R15B, EIF2S3 and EIF2B1) cause monogenic diabetes, highlighting the importance of regulated eukaryotic translation initiation factor $2 \alpha$ (eIF $2 \alpha)$ phosphorylation for human $\beta$-cell function and survival $(3,5,6,7,8)$. eIF $2 \alpha$ phosphorylation is a key component of early ER stress signaling, since it attenuates protein translation and alleviates ER workload. eIF $2 \alpha$ can be phosphorylated by four kinases, each activated by distinct cellular stresses: PKR (interferon-induced dsRNAactivated eIF2 $\alpha$ protein kinase R), PERK, GCN2 (general control non-derepressible-2 kinase), and HRI (hemeregulated inhibitor) (9).

DnaJ heat shock protein family (Hsp40) member C3 (DNAJC3), also known as p58 ${ }^{\mathrm{IPK}}$, is a Hsp40 family member, originally described as a PKR inhibitor $(10,11$, 12). Later reports showed that DNAJC3 also interacts with and inhibits PERK $(13,14)$ and GCN2 (15). DNAJC3 transcription is activated during ER stress, decreasing phospho-eIF $2 \alpha$ signaling in later phases of the ER stress response and promoting translational recovery (14). DNAJC3 deficiency leads to exaggerated eIF2 $\alpha$ phosphorylation, prolonged inhibition of protein synthesis and apoptosis in HeLa cells, fibroblasts and mouse embryonic stem cells $(13,14)$. Dnajc3-deficient mice developed hypoinsulinemic diabetes $(16,17)$. These mice had abnormal islet morphology, $\beta$-cell apoptosis and decreased islet mass $(16,17)$. Synofzik et al. were the first to report recessive DNAJC3 loss-of-function mutations in two families causing young-onset diabetes and neurodegeneration (18), identifying another form of diabetes caused by dysregulated PERK expression/ signaling.

Here we describe two unrelated patients with novel DNAJC3 loss-of-function mutations. To evaluate the role of DNAJC3 in $\beta$-cell function and survival we generated DNAJC3-deficient rodent and human $\beta$-cell models. Our data show that DNAJC3 deficiency leads to $\beta$-cell loss through the activation of the pro-apoptotic proteins BIM and PUMA and the mitochondrial pathway of apoptosis.

\section{Subjects and methods}

\section{Patients}

We studied two unrelated patients with juvenile-onset syndromic diabetes. Patients and their families gave their written informed consent to participate in the study, which was approved by the ethics committees of SaintAntoine Hospital, Saint-Louis Hospital or Hospice Civils de Lyon. Genomic DNA was extracted from peripheral blood.

\section{Whole exome sequencing}

Exome sequencing was performed on the sequencing platform of the Institut de Génétique et de Biologie Moléculaire et Cellulaire (Illkirch, France). Exons were captured with in-solution enrichment (SureSelectXT Target Enrichment System for Illumina Paired-End Sequencing Library version v1.5 Nov 2012 (Part Number G7530-90000); Agilent). The exon capture kit was Human All Exon $50 \mathrm{Mb}$ - ELID S02972011. Genomic DNA was sequenced using HiSeq 2500 (Illumina, San Diego, USA) as paired-end 100-base reads according to the manufacturer's protocol. Image analysis and base calling were performed using CASAVA v1.8.2 (Illumina). Reads were mapped onto reference genome hg19 using BWA v0.6.1 (19). Variant discovery was done using GATK v2.5-2 (20) and Samtools v0.1.18 (19). Exome variants were analyzed using an in-house python pipeline on genetic variation annotation. Variants were filtered based on quality (variant quality (Phred Q score) $>20$, genotype quality $>20$ and depth $\geq 5 \times$ ), predicted coding consequence (missense, nonsense, splice-site, and coding insertion/deletion - frameshift or inframe) and rarity, based on public databases (Exome Aggregation Consortium (ExAC, release 0.3, 60,706 individuals) (21); Exome Variant Server (EVS, release ESP6500SI-V2, 6503 individuals) and SNP database (dbSNP, v.150)). Data from 20 subjects sequenced on this platform were used to filter platform-specific artifacts. Variants with minor allele frequency (MAF) $>0.005$ in these databases were excluded. Filtering of exome sequencing results was performed for homozygous or compound heterozygous variants and known monogenic diabetes gene variants. Allele frequencies of variants were further investigated in the Genome Aggregation Database, ExAC extension 
(gnomAD, 141,456 individuals) and the Greater Middle East Variome (GME, 2497 individuals) (22).

\section{Mutation confirmation and screening by DNA sequencing}

DNAJC3 variants identified in patients 1 and 2 by whole exome sequencing were confirmed by Sanger sequencing. Screening for DNAJC3 mutations in patients with likely monogenic inheritance with suggestive clinical features (32 index cases and their families) was performed by whole exome sequencing or Sanger sequencing of DNAJC3 coding exons on PCR-amplified DNA using Applied Biosystems 3730 DNA Sequencer. PCR and sequencing primers are provided in Supplementary Table 1 (see section on supplementary materials given at the end of this article).

Genotyping of the two DNAJC3 variants identified in patient 1 and family members of family 1 (6 subjects) was performed by PCR-restriction fragment length polymorphism (RFLP) genotyping using specific amplification primers and restriction enzymes (Supplementary Table 2) that differentiate the two alleles, followed by agarose gel electrophoresis.

\section{Culture of INS-1E cells, FACS-purified primary rat $\beta$-cells and human islets}

Rat insulin-producing INS-1E cells (kindly provided by C Wollheim, Centre Medical Universitaire, Geneva, Switzerland) were cultured as described (23) and used at passages 60-72. INS-1E cells were exposed to $25 \mu \mathrm{M}$ cyclopiazonic acid (CPA, Sigma-Aldrich); the control condition contained the same DMSO dilution. Male Wistar rats (Charles River Laboratories) were used according to the guidelines of the Belgian Regulations for Animal Care, following approval by the local Ethical Committee. Rat islets were isolated, dispersed into single cells and $\beta$-cells purified by FACS (FACSAria, BD Biosciences, San Jose, USA) as described (24), yielding a purity of $91 \pm 2 \%$. Human islets (five non-diabetic donors, age $67 \pm 22$ years, BMI $25 \pm 2$ $\mathrm{kg} / \mathrm{m}^{2}$ ) were isolated by collagenase digestion and density gradient purification in Pisa (25), with the approval of the local Ethical Committee. Islets were cultured and dispersed as described (26). The percentage of $\beta$-cells, assessed by insulin immunofluorescence (23), was $40 \pm 12 \%$.

\section{Culture of human induced pluripotent stem cells and differentiation into $\beta$-cells}

Three different induced pluripotent stem cell (iPSC) lines (HEL115.6, HEL185.3 and 1023.A) derived from healthy donors were cultured and differentiated into $\beta$-cells as described (27, 28, 29, 30, 31). HEL115.6 and HEL185.3 iPSCs were generated at the University of Helsinki; 1023.A iPSCs were kindly provided by DM Egli (University of Columbia). The iPSCs had normal karyotype, classical stem cell colony morphology and expressed pluripotency markers, as shown in (30) and Supplementary Figs 5 and 6. iPSCs were maintained in E8 medium in Matrigelcoated plates (Corning) and subsequently seeded at 2.5$3.0 \times 10^{6}$ cells per $3.5 \mathrm{~cm}$ well in E8 medium containing 5 $\mu \mathrm{M}$ ROCK inhibitor (StemCell Technologies) $24 \mathrm{~h}$ prior to the 7-stage differentiation. When reaching the pancreatic progenitor stage, cells were plated into microwell plates at 750-900 cells/microwell (AggreWell, Stem Cell Technologies) to allow formation of islet-like aggregates. Prior to RNA interference, stage 7 aggregates were dispersed as described (32). Aggregates were incubated in $0.5 \mathrm{mM}$ EDTA at room temperature for $6 \mathrm{~min}$, exposed to Accumax (Sigma-Aldrich) for $8 \mathrm{~min}$ and then dispersed by gentle pipetting. Knockout serum (Gibco) was added to quench the dissociation process, and cells were seeded at $5 \times 10^{4}$ cells per $6.4 \mathrm{~mm}$ well in stage 7 medium. Stage 7 cells were exposed to $1 \mu \mathrm{M}$ thapsigargin (Sigma-Aldrich) for $48 \mathrm{~h}$; the same DMSO dilution was used in control condition.

\section{RNAi}

Cells were transfected with siRNAs for DNAJC3 (rat Dnajc3 s133632 in Fig. 3A, B, C and D, rat Dnajc3 s133633 in Figs 3E, 4 and Supplementary Figs 3, 4; human DNAJC3 s11188 in Figs 3F, 5C and Supplementary Fig. 7, and s11190 in Supplementary Fig. 3D, all from Ambion, Life Technologies) and with previously validated siRNAs for Bim, DP5, PUMA (33) and Bad (34). A 21-nucleotide duplex RNA (Qiagen) that does not affect $\beta$-cell function, gene expression or viability (35) was used as negative control. siRNA-Lipofectamine RNAiMAX (Invitrogen, Life Technologies) complexes were formed in OptiMEM. Transfection was done using $30 \mathrm{nM}$ siRNA and Lipofectamine at a final dilution of $1 / 500$ in INS-1E cells, $1 / 400$ in primary rat $\beta$-cells and $1 / 250$ in dispersed human islets and iPSC-derived $\beta$-cells. Cells were studied $72 \mathrm{~h}$ after transfection. To set up the transfection conditions for iPSC- $\beta$-cells, the reporter siRNAs BLOCK-iT Alexa Fluor Red Fluorescent Control and BLOCK-iT Fluorescent Oligo (ThermoFisher Scientific) were used with Lipofectamine RNAiMAX or Lipofectamine 2000 (Invitrogen, Life Technologies). 


\section{mRNA extraction and real time PCR}

Poly(A)+-RNA was extracted from cells using oligo-dT 25-coated polystyrene Dynabeads (DYNAL, Oslo, Norway) and reverse-transcribed with GeneAmp RNA PCR kit (Perkin-Elmer) or Reverse Transcriptase Core Kit (Eurogentec). For real time PCR on MyiQ2 or CFX Connect (BIO-RAD), cDNA was added to IQ SYBR Green Supermix (BIO-RAD). A standard curve was used to calculate gene expression as copies/microliter. Values were normalized to expression of reference genes glyceraldehyde-3-phosphate dehydrogenase (GAPDH), $\beta$-actin (ACTB) and/or ornithine decarboxylase antizyme 1 (OAZ1). Primer sequences are provided in Supplementary Table 3.

\section{Glucose-stimulated insulin secretion and $\beta$-cell apoptosis}

INS-1E cells were kept for $30 \mathrm{~min}$ in glucose-free RPMI1640 supplemented with 5\% FBS and then incubated in glucose-free modified Krebs-Ringer bicarbonate HEPES solution (KRBH) for $30 \mathrm{~min}$. Insulin secretion was induced by KRBH containing 1.7 or $16.7 \mathrm{mM}$ glucose $\pm 10 \mu \mathrm{M}$ forskolin for $30 \mathrm{~min}$ (36). Insulin was measured by ELISA (Mercodia, Uppsala, Sweden) in cellfree supernatants and acid ethanol-extracted cell lysates. Insulin levels were normalized to total protein (Bradford assay, BIO-RAD).

The percentage of apoptotic cells was assessed using the DNA-binding dyes Hoechst $33342(10 \mu \mathrm{g} / \mathrm{mL})$ and propidium iodide $(5 \mu \mathrm{g} / \mathrm{mL})(37,38)$. A minimum of 400 cells was counted for each experimental condition by two observers, one of them unaware of the experimental conditions.

\section{Western blot}

Cells were lysed using Laemmli buffer ( $60 \mathrm{mM}$ Tris, $\mathrm{pH}$ $6.8,10 \%$ glycerol, $1 \%$ SDS, $0.001 \%$ bromophenol blue and $5 \% \quad \beta$-mercaptoethanol). To assess cytochrome C release, cells were harvested in PBS $48 \mathrm{~h}$ after transfection. After centrifugation, cytosolic lysis buffer containing $0.8 \mu \mathrm{g} / \mu \mathrm{L}$ digitonin was added to the pellet. Cells were vortexed for $30 \mathrm{~s}$ and centrifuged at $4^{\circ} \mathrm{C}$ at $20000 \mathrm{~g}$ for 1 min. Supernatant was separated as cytoplasmic fraction and pellet as mitochondrial fraction. Lysates were boiled for $5 \mathrm{~min}$, separated by SDS-PAGE in 10-12\% gel, transferred to nitrocellulose/PVDF membranes (BIO-RAD) and immunoblotted using antibodies (Supplementary Table 4). Signals were detected using chemiluminescence supersignal (Pierce) with ChemiDoc (BIO-RAD) and densitometric bands quantified with ImageJ.

\section{Statistical analysis}

Data are presented as scatterplots with bars indicating mean \pm S.D. of the indicated number $(n)$ of independent experiments. Two-sided Student's paired $t$-test or ratio $t$-test was used for pairwise comparisons. Paired two-way ANOVA or mixed effects model analysis (the latter in case of a missing value), followed by Bonferroni correction were applied for multiple comparisons. A $P$-value $<0.05$ was considered statistically significant.

\section{Results}

\section{Clinical presentation of patients with $D N A J C 3$ loss-of-function mutations}

We studied two unrelated patients presenting with juvenile-onset syndromic diabetes (Fig. 1 and Table 1).

\section{Patient 1}

Patient 1 (family 1), a French girl of Armenian ancestry, was born to healthy non-consanguineous parents. She had intrauterine growth retardation (weight: $2.430 \mathrm{~kg}$, length: $46 \mathrm{~cm}$, head circumference: $32.5 \mathrm{~cm}$ at birth at 37 weeks of gestational age). She had growth retardation and short adult stature $(143 \mathrm{~cm},-3$ s.D.) despite discontinuous growth hormone $(\mathrm{GH})$ treatment from age 5 to 13 years. GH and IGF1 levels, as well as GH glucagon test were normal, but normal growth was observed during GH treatment periods. She had microcephaly (adult head circumference: $51 \mathrm{~cm},-2.5$ s.D.). At the last examination at age 30 years, her weight was normal for her height (43 kg, BMI $21.0 \mathrm{~kg} /$ $\mathrm{m}^{2}$ ). From age 9 months, she presented with hypoglycemia after short fasting. Diabetes was discovered at age 12 years as part of GH treatment follow-up, and persisted after GH discontinuation. She was treated with oral glucose-lowering agents, and a GLP- 1 analog was added at age 26 years. AntiGAD and anti-IA2 antibodies were negative at diabetes onset. Further exploration at age 19 years showed fasting glycemia of $6.4 \mathrm{mM}$, insulinemia of $5 \mathrm{mIU} / \mathrm{L}$ (normal values 3-25) and C-peptide of 314 pM (normal 200-1300); HOMA2-\%B was 43.4 and HOMA2-\%S 144.3 (HOMA2 calculator, https://www.dtu.ox.ac.uk/homacalculator). Postprandial insulin increased to $40 \mathrm{mIU} / \mathrm{L}$ and C-peptide to $1144 \mathrm{pM}$. She had moderate steatorrhea, with no 


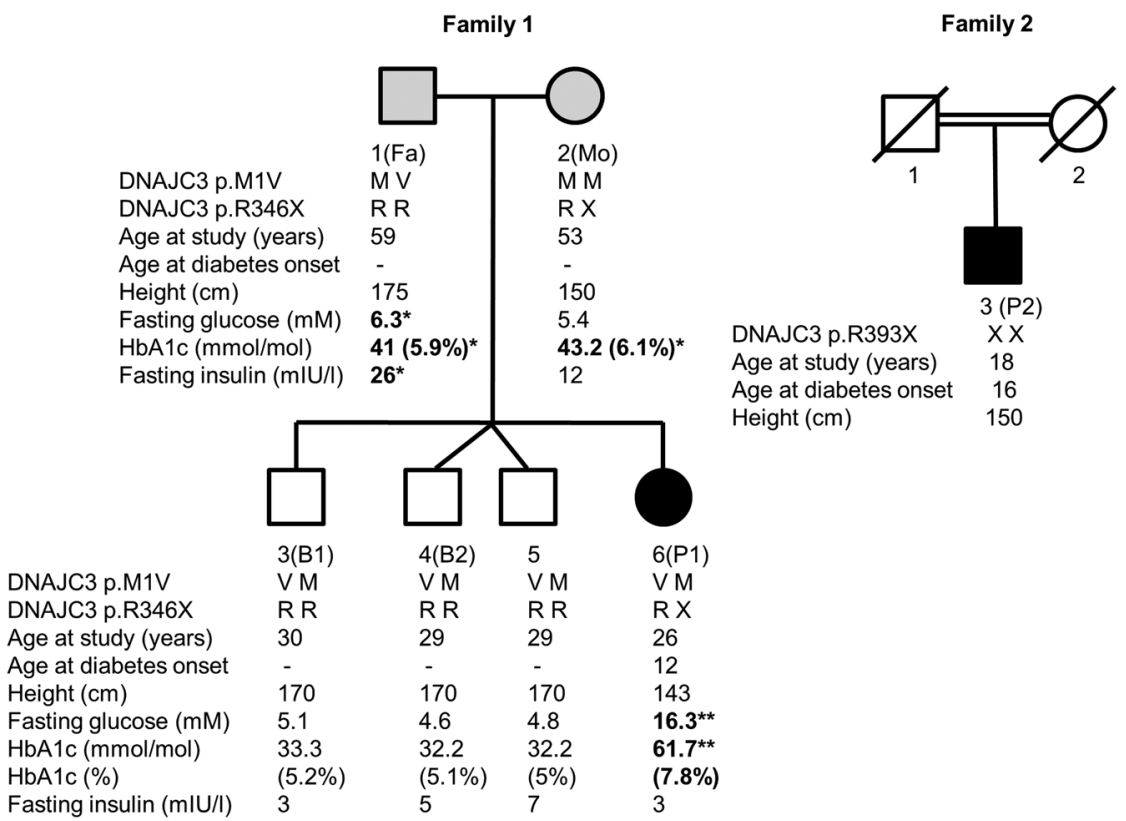

\section{Figure 1}

Clinical and genetic characteristics of two families with novel DNAJC3 mutations. Diabetic probands (P1 and P2) are shown in black symbols. Diabetes status of relatives in family 1 was established based on fasting glucose and $\mathrm{HbA1c}$. Parents from family 2 were not available for clinical or genetic investigation. Impaired fasting glucose (5.6-6.9 mM) or prediabetes based on $\mathrm{HbA} 1 \mathrm{C}$ (5.7-6.4\%) and high fasting insulin (>25 $\mathrm{mlU} / \mathrm{L}$ ) are indicated by *; values in the diabetic range are shown by **. Genotype status of the probands ( $\mathrm{P} 1$, compound heterozygous; $\mathrm{P} 2$, homozygous) and available family members is shown for the three newly identified DNAJC3 mutations. clinical/biological signs of malabsorption, but declined further investigation of exocrine pancreas insufficiency.

She presented with neonatal hypotonia and gait disorder since walking acquisition (slightly delayed at 20 months), suggestive of early-onset cerebellar ataxia. This was confirmed at 8 years by clinical examination and brain MRI, showing severe vermis hypoplasia with pontocerebellar atrophy (cerebellar and midbrain, Supplementary Fig. 1). At 14 years, proprioceptive ataxia was diagnosed, due to demyelinating peripheral sensorimotor neuropathy. Electroneuromyography showed decreased nerve conduction velocity of 25-35 $\mathrm{m} / \mathrm{s}$ for upper and lower limbs (normal $>45 \mathrm{~m} / \mathrm{s}$ ). At neurological examination at 30 years, she had kinetic and static ataxia, areflexia, pes planus, nystagmus, abnormal movements of hands (syncinesia) and tremor. She scored 16/40 on the Scale for the Assessment and Rating of Ataxia.

Language acquisition was delayed (4 years). She had school difficulties, with calculation deficit, but no clear cognitive impairment. She had bilateral sensorineural hearing loss diagnosed at 6 years, while her audiogram had been normal at age 1 year.

Subclinical hypothyroidism was diagnosed at age 19 years, with high TSH, normal T4 and T3 and no thyroid autoantibodies; thyroid ultrasound was normal. She had facial dysmorphism, with deviation of the mandible and nasal septum, wide and prominent nasal bridge, bulbous nose, slight hypertelorism, microretrognathia (surgically repaired), protruding ears and low hairline. She had minor skeletal deformities of chest and hip (congenital dysplasia) and a nasal voice.
Patient 2

Patient 2 (family 2) was an Algerian boy born to consanguineous parents. He had normal weight and height at birth, failure to thrive since early childhood, and reached a height of $150.5 \mathrm{~cm}(-4$ s.D.) and weight of $36 \mathrm{~kg}$ (BMI $15.9 \mathrm{~kg} / \mathrm{m}^{2}$ ) at the last examination at age 18 years, despite irregular GH treatment starting at 12 years. At age 5 years, hypothyroidism was diagnosed, with high TSH and low T4; thyroid ultrasound was normal. He had bilateral hearing loss. He also presented with facial dysmorphism, with nasal septum deviation, prominent malformed ears and low hairline. He had skeletal deformities with dorsal cyphosis and pectus carinatum, and a nasal voice. Diabetes was diagnosed at 16 years and insulin-treated; further information on his diabetes is lacking. His intellectual status was not documented, and the patient was lost to follow-up.

Exome sequencing performed in patients 1 and 2 identified bi-allelic DNAJC3 loss-of-function mutations (Fig. 2A). DNAJC3 is highly expressed in human pancreas and islets (Fig. 2B), consistent with a role for this protein in $\beta$-cells. Patient 1 was compound heterozygous for a nonsense mutation (c.1036C $>\mathrm{T}$, p.R346*) transmitted by the mother and for a start codon mutation (c.1A>G, p.M1V) transmitted by the father. Three healthy siblings were heterozygous for the p.M1V mutation. Lymphoblasts from patient 1 had normal DNAJC3 mRNA (Fig. 2C) and undetectable DNAJC3 protein levels (Fig. 2D), confirming that both DNAJC3 mutations result in loss-of-function. Patient 2 was homozygous for another nonsense mutation 


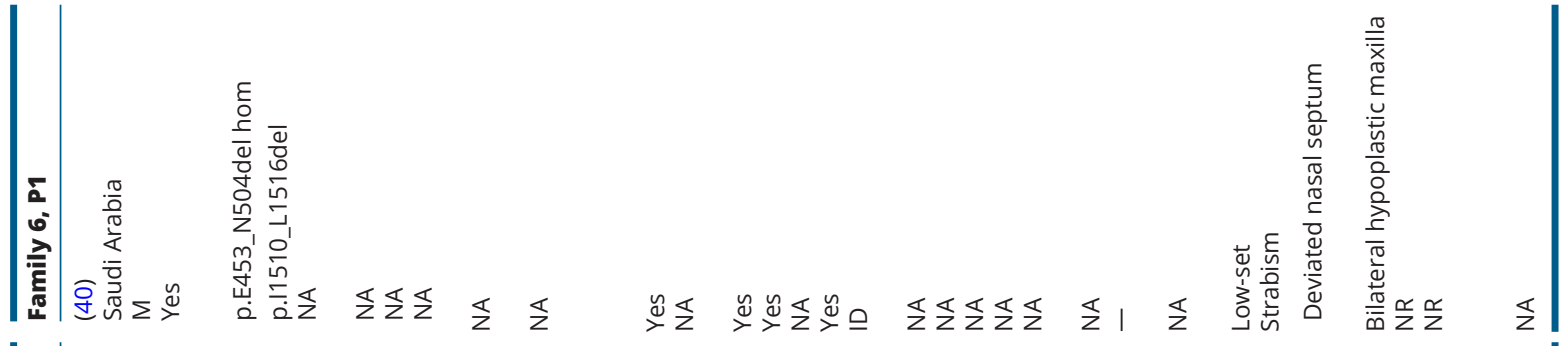

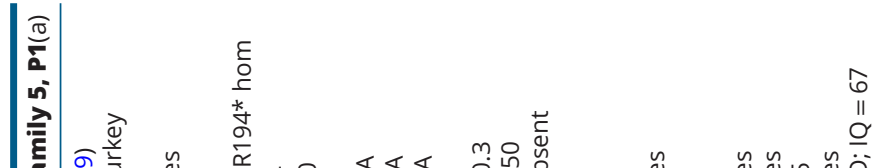

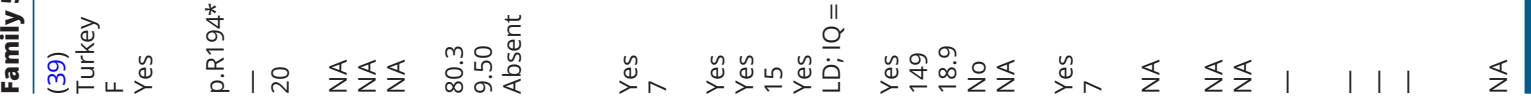

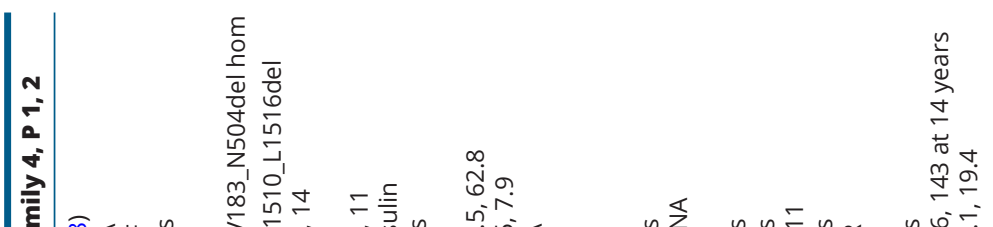

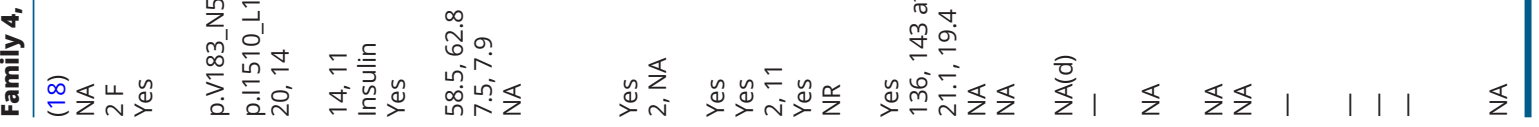
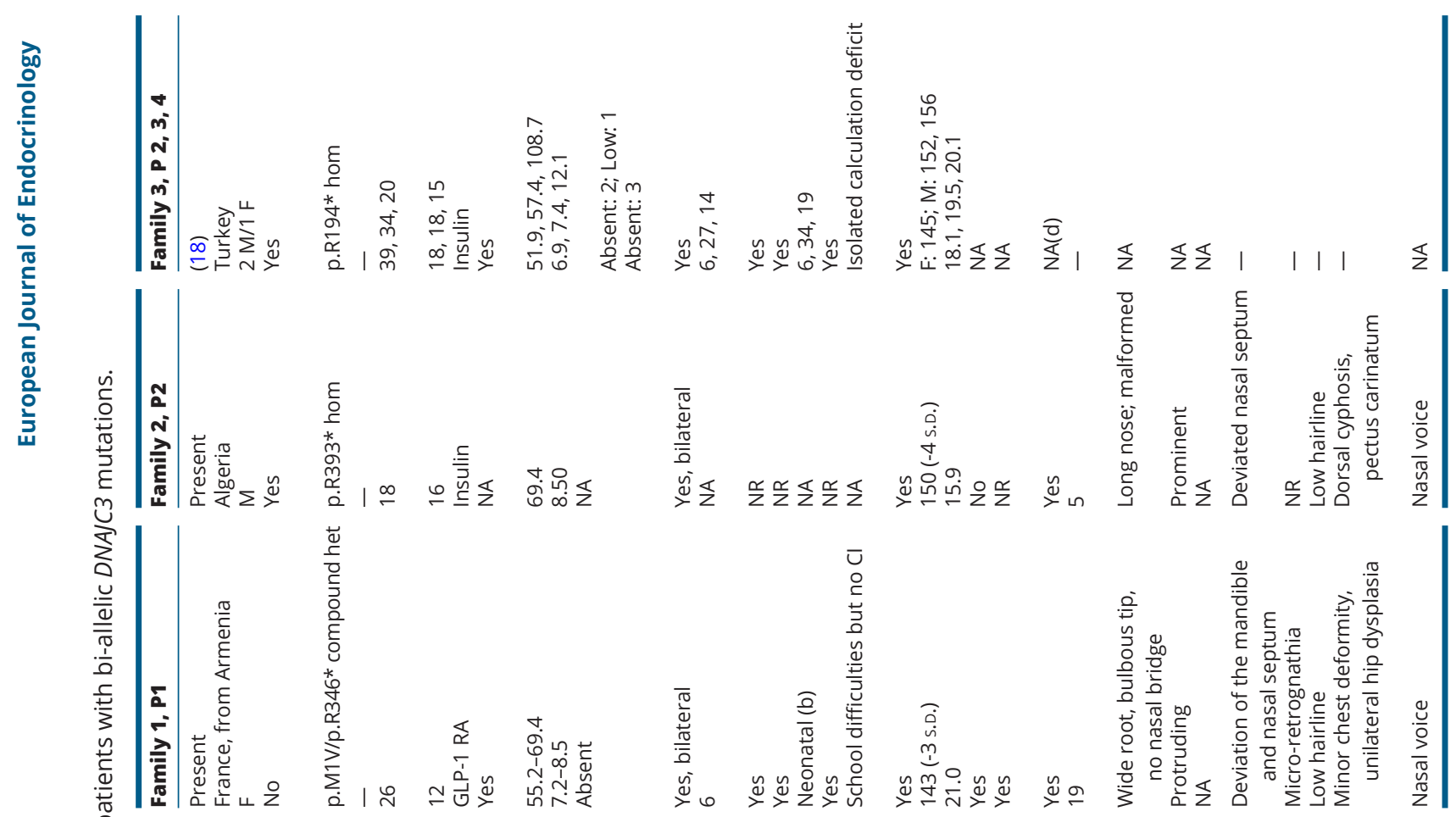

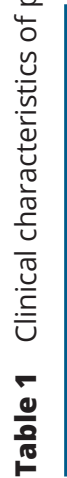
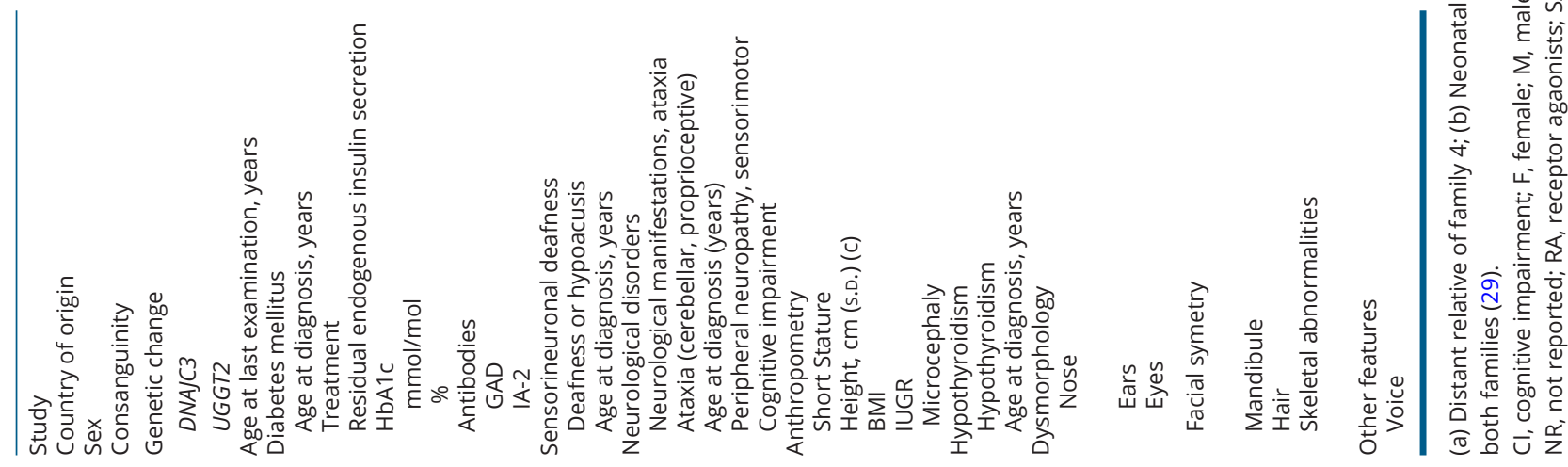
(c.1177C>T, p.R393*). All three mutations were absent from public databases (gnomAD, EVS, GME).

No DNAJC3 mutations were identified in 32 additional diabetic patients with likely monogenic inheritance sharing neurological characteristics, hypothyroidism and short stature.
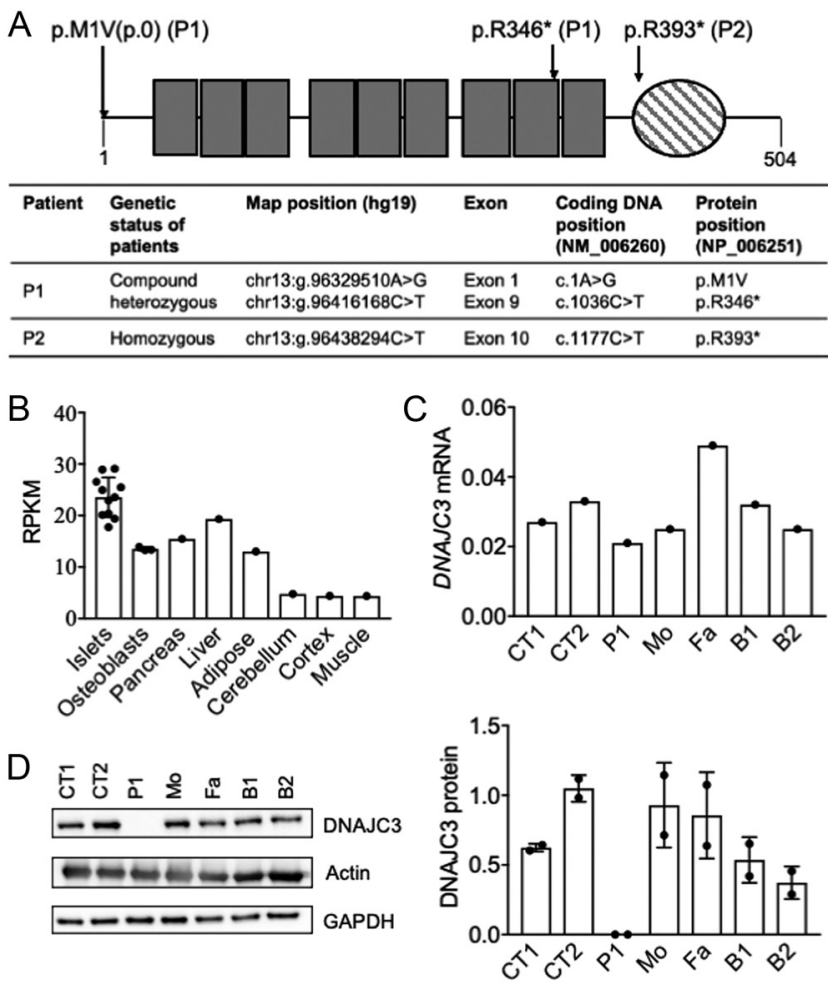

Figure 2

DNAJC3 loss-of-function mutations in two unrelated patients.

(A) Description and schematic protein representation of DNAJC3 mutations identified in patients 1 (P1) and 2 (P2). Protein domains: tetratricopeptide repeat (gray boxes), Dnal molecular chaperone homology domain (hatched circle). (B) DNAJC3 expression (in RPKM, by RNA-seq) in human tissues from GTEx (v4.p1) (64), human islets from $(65,66)(n=10)$ and osteoblasts from (67) $(n=3)$. (C) DNAJC3 mRNA levels were examined by qPCR in lymphoblasts from two healthy controls (CT1 and CT2), patient 1 (P1) and heterozygous family members mother (Mo), father (Fa) and two brothers (B1 and B2) and normalized to the geometric mean of the reference genes GAPDH, ACTB and OAZ1. (D) Representative Western blot showing DNAJC3 protein expression in lymphoblasts (left) and densitometric quantification of 2 independent experiments (right panel). DNAJC3 expression was normalized to the geometric mean of the loading controls actin and GAPDH.

\section{Review of clinical manifestations of patients with bi-allelic DNAJC3 loss-of-function mutations}

In addition to the cases described here, patients with homozygous DNAJC3 mutations from three unrelated families have been reported $(18,39,40)$ (Table 1). Their clinical presentation comprised diabetes and multisystemic neurodegeneration, referred to as combined cerebellar and peripheral ataxia, with hearing loss and diabetes mellitus (ACPHD) syndrome (OMIM \#616192) (18), later completed by hypothyroidism (39) and facial dysmorphology (40). We confirm these clinical features in our patients, with ears and nose malformations, deviated nasal septum, facial asymmetry and low hairline. Microcephaly was reported in patient 1 . Growth retardation and short stature, with low/normal BMI, were observed in both patients; intrauterine growth retardation, reported for the first time in patient 1 but not in patient 2, is most likely a manifestation of this syndrome. Moderate steatorrhea (patient 1) may suggest exocrine pancreas deficiency. Both patients had bone deformities, with minor chest deformity and congenital hip dysplasia (patient 1) that have not been previously reported and are likely novel characteristics of the syndrome. Nasal voice, found in both patients, is a new feature and may be caused by deviated nasal septum or velopharyngeal incompetence resulting from nervous system dysfunction.

All DNAJC3 mutations including the three novel mutations identified here are loss-of-function mutations (Fig. 2A and Table 1).

\section{Diabetes status of relatives suggests increased adult-onset diabetes risk in heterozygous carriers}

Patient 1's parents had impaired fasting glucose/pre-diabetes, while her three healthy brothers had normal fasting glycemia (Fig. 1). Family 1 had a high incidence of adultonset diabetes in both parents' relatives, consistent with dominant inheritance of increased adult-onset diabetes risk in heterozygous DNAJC3 mutation carriers (Supplementary Fig. 2). Unfortunately, these distant relatives were not available for clinical/genetic study. Patient 2's family history also revealed several adult-onset diabetes cases in the paternal line; parents and relatives were not available for study. We searched exome sequencing data from the Type 2 Diabetes Knowledge Portal available online on 45,231 subjects comprising 20,791 diabetes cases and 24,440 controls (type2diabetesgenetics.org) (41). Only one subject carried a DNAJC3 protein-truncating variant, providing no statistical power to test this hypothesis. There was a history 
of short stature among some relatives of patient 1 , which does not, however, cosegregate with heterozygous DNAJC3 mutation carrier status based on the available information (Supplementary Fig. 2).

\section{DNAJC3 deficiency does not impair insulin secretion but induces $\beta$-cell apoptosis}

In order to evaluate the impact of DNAJC3 deficiency on $\beta$-cell function and survival, an in vitro $\beta$-cell model of DNAJC3 loss-of-function was established by RNA interference. Dnajc3 mRNA and protein levels were efficiently inhibited by 85 and $47 \%$, respectively, in INS-1E cells (Fig. 3A and B). A second siRNA targeting a different Dnajc3 mRNA region similarly inhibited mRNA expression (by 82\%, Supplementary Fig. 3A).

$\beta$-cell insulin content was unchanged by DNAJC3 depletion (Fig. 3C). Insulin secretion in response to low $(1.67 \mathrm{mM})$ and high glucose $(16.7 \mathrm{mM})$ was similar in Dnajc3-deficient and -competent cells (Fig. 3C). Dnajc3 knockdown using the second siRNA produced similar findings (Supplementary Fig. 3B).

Dnajc3 depletion induced INS-1E $\beta$-cell apoptosis (Fig. 3D), and this was confirmed using a second siRNA
(Supplementary Fig. 3C). Dnajc3 knockdown also induced apoptosis in FACS-purified primary rat $\beta$-cells (Fig. 3E) and, importantly, in human islet cells (Fig. 3F and Supplementary Fig. 3D).

\section{DNAJC3 deficiency activates the pro-apoptotic protein Bim and the mitochondrial pathway of apoptosis}

To study the apoptotic pathway induced by DNAJC3 deficiency, we evaluated mitochondrial cytochrome c release. INS-1E cells were exposed to the synthetic ER stressor CPA to sensitize them to cell death. Cytochrome c levels were increased in the cytoplasmic fraction of Dnajc3depleted $\beta$-cells and decreased in the non-cytoplasmic fraction, which includes mitochondria (Fig. 4A). This suggests that DNAJC3 deficiency elicits $\beta$-cell apoptosis through the intrinsic (mitochondrial) pathway of apoptosis.

Bcl-2 family proteins are crucial controllers of mitochondrial $\beta$-cell apoptosis (42). To identify the responsible pro-apoptotic Bcl-2 family members, we double-knocked down Dnajc3 and DP5, PUMA, Bim and Bad. Bim knockdown (Fig. 4B) fully protected the
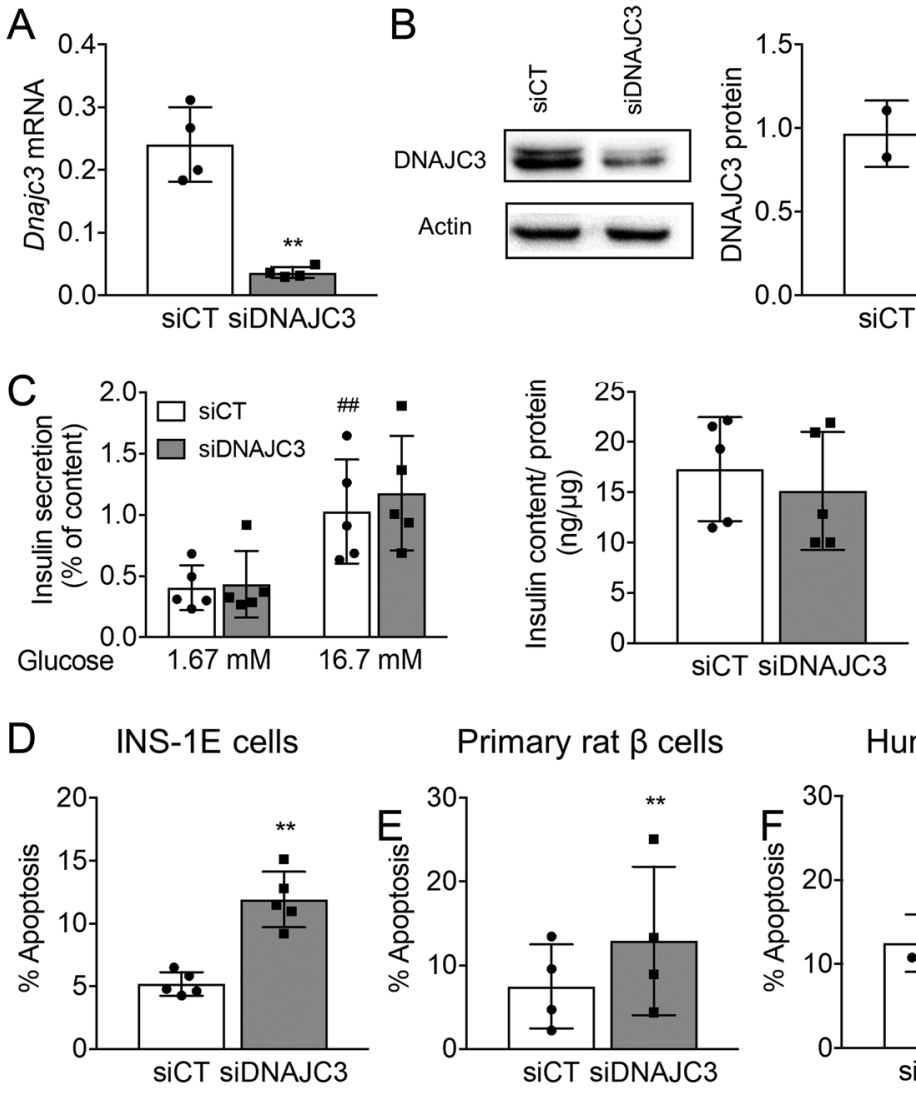

Primary rat $\beta$ cells

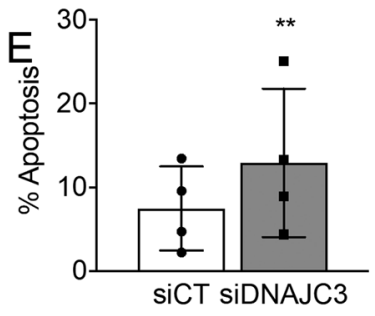

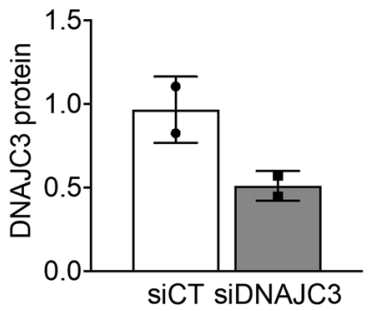

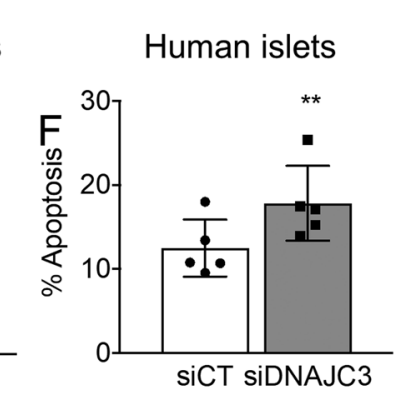

\section{Figure 3}

DNAJC3 silencing does not affect insulin secretion and induces $\beta$-cell apoptosis. $\beta c e l l s$ were transfected with control (siCT) and DNAJC3 siRNA. (A) Dnajc3 mRNA levels in INS-1E cells after transfection $(n=4)$. (B) Representative Western blot of transfected INS-1E cells and densitometric quantification of Dnajc3 protein expression in two independent experiments. Actin was used as loading control. (C) Insulin secretion (left panel) was induced by 1.67 or $16.7 \mathrm{mM}$ glucose $48 \mathrm{~h}$ after transfection, and expressed as percent of insulin content. INS-1E cell insulin content (right panel) is corrected for total protein ( $n=5)$. (D, E and F) Apoptosis was examined by propidium iodide and Hoechst 33342 staining in INS-1E cells $(n=5)(D)$, primary rat $\beta$-cells $(n=4)(E)$ and dispersed human islet cells $(n=5)(\mathrm{F})$ transfected with siCT or siDNAJC3. ${ }^{* *} P<0.01$ vs SiCT and ${ }^{\# \# P}<$ 0.01 vs $1.67 \mathrm{mM}$ glucose. 

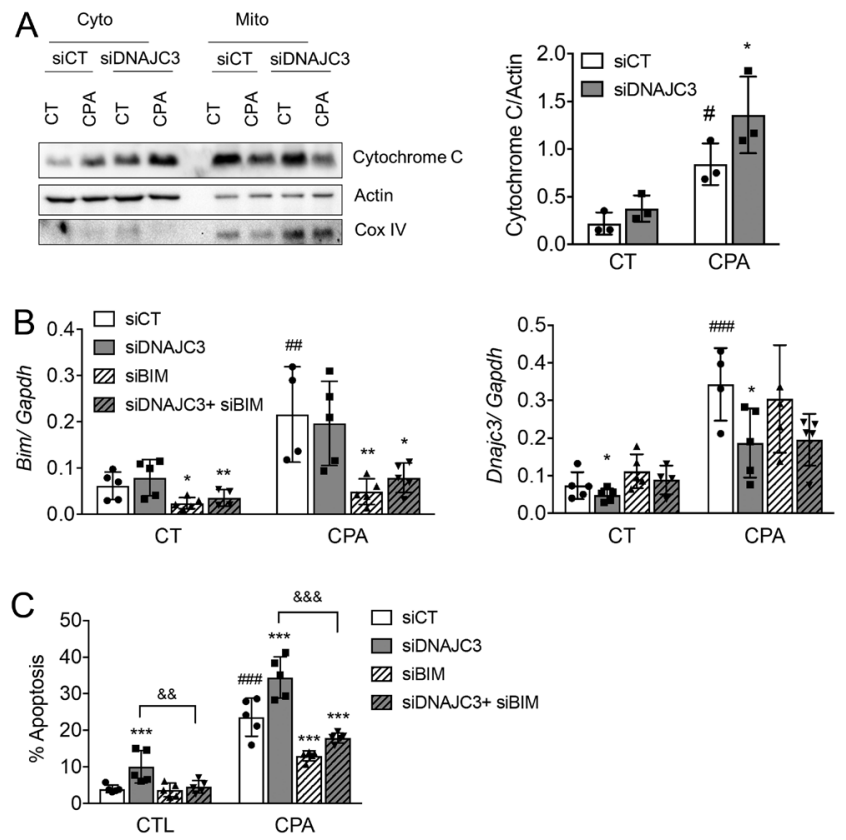

\section{Figure 4}

DNAJC3 deficiency activates the mitochondrial pathway of apoptosis in a Bim-dependent manner. (A) Mitochondrial cytochrome $c$ release was detected by Western blot in INS-1E cells after Dnajc3 knockdown and 8 h CPA treatment. The left lanes (Cyto) show the cytoplasmic fraction and the right lanes (Mito) a non-cytoplasmic fraction that includes mitochondria. Cox IV was used as mitochondrial loading control and actin as cytoplasmic loading control. Right panel: densitometric quantification of cytoplasmic cytochrome C. CT denotes control. (B) Bim and Dnajc3 mRNA in INS-1E cells transfected with SiCT or siRNA targeting DNAJC3 and/or Bim and treated or not with CPA for $16 \mathrm{~h}(n=4-5)$. (C) Apoptosis was examined by propidium iodide and Hoechst 33342 staining in the same experimental conditions as in panel $\mathrm{B}(n=5)$. ${ }^{*} P<0.05, * * P<$

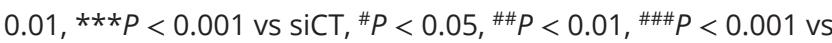
non-treated cells $(C T), \& \& P<0.01$ and $\& \& \& P<0.001$ as indicated.

cells from DNAJC3 deficiency-related apoptosis (Fig. 4C), but no protection was observed following efficient DP5, PUMA or Bad knockdown (Supplementary Fig. 4). These data identify Bim as the key activator of mitochondrial $\beta$-cell apoptosis due to DNAJC3 deficiency.

\section{DNAJC3 deficiency sensitizes human iPSC-derived $\beta$-cells to ER stress-induced apoptosis}

To confirm these results in a human cell model, human iPSCs were differentiated into $\beta$-cells. At the end of the
A
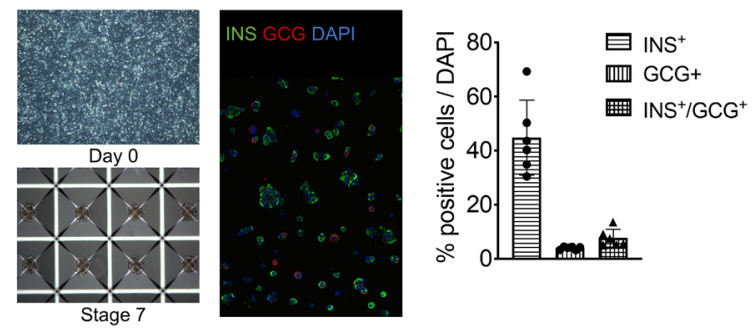

B
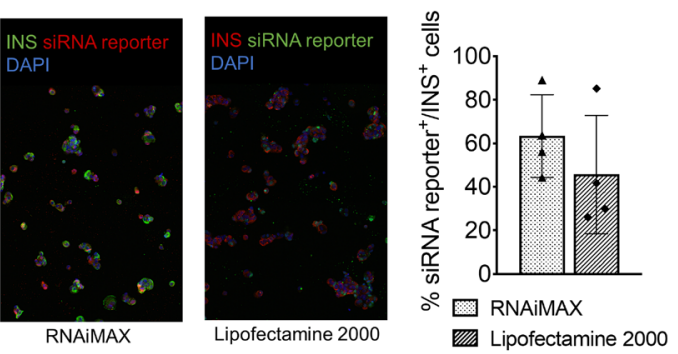

C $\square$ siCT
$\square$ siDNAJC3

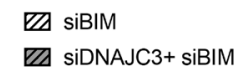

Е siPUMA
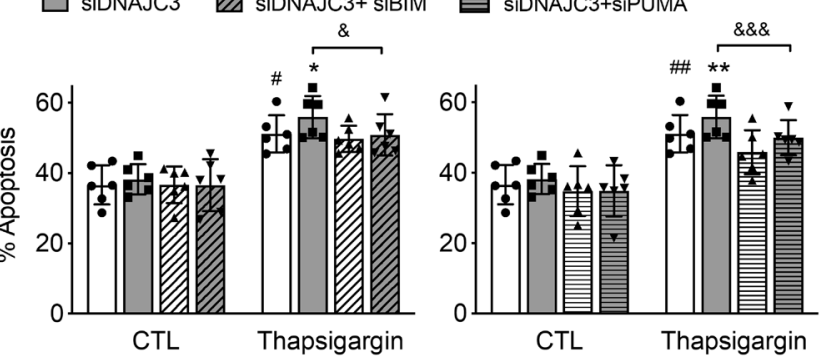

Figure 5

DNAJC3 deficiency sensitizes human iPSC- $\beta$-cells to ER stress-induced apoptosis via BIM and PUMA. (A) iPSCs were differentiated into $\beta$-cells following a seven-stage protocol. Left panel shows cells at day 0 (iPSCs) and at the end of the differentiation process. The yield of insulin- and glucagonpositive cells was measured at the end of stage 7 by immunocytochemistry (central and right panel). Insulin is stained in green, glucagon in red and nuclei are visualized with DAPI in blue. Hormone-positive cells are expressed as percentage of total cells $(n=6)$. (B) iPSC-derived $\beta$-cells were transfected with siRNA reporters using RNAiMAX or Lipofectamine 2000. Insulin- and siRNA reporter-positive cells were detected by immunocytochemistry. Left panel shows representative images and right panel quantification of siRNA reporter-positive cells expressed as percentage of insulinpositive cells $(n=4)$. (C) iPSC-derived $\beta$-cells were transfected with control (SiCT) or DNAJC3 siRNA alone or together with siRNAs targeting BIM or PUMA $(n=6)$. Apoptosis was examined by propidium iodide and Hoechst 33342 staining. ${ }^{\star} P<0.05,{ }^{*} * P<0.01$ vs siCT, ${ }^{\#} P<0.05,{ }^{\#} P<0.01$ vs nontreated cells $(C T L), \& P<0.05$ and $\& \& \& P<0.001$ as indicated. 
differentiation (stage 7), the islet-like aggregates contained over $40 \% \beta$-cells, and a few percent $\alpha$ - and bihormonal cells (Fig. 5A). To set up siRNA transfection in this model, two fluorescent siRNA reporters were introduced with Lipofectamine 2000 or RNAiMAX. The latter resulted in a slightly higher yield of transfected insulin-positive cells (Fig. 5B) and was selected for subsequent experiments to silence DNAJC3. Because CPA did not induce ER stress in iPSC- $\beta$-cells, we used the stronger ER stressor thapsigargin (27) that induced DNAJC3 expression by three-fold (Supplementary Fig. 7A and C). DNAJC3 mRNA was inhibited by 50-60\% upon RNAi (Supplementary Fig. 7A and C). DNAJC3 depletion sensitized iPSC-derived $\beta$-cells to apoptosis induced by thapsigargin (Fig. 5C). Both BIM and PUMA knockdown (Supplementary Fig. 7B and D) protected DNAJC3-silenced $\beta$-cells from apoptosis (Fig. 5C), confirming the role of these Bcl-2 family proteins as mediators of mitochondrial apoptosis in human $\beta$-cells lacking DNAJC3.

\section{Discussion}

Here we report two unrelated cases with novel DNAJC3 loss-of-function mutations, presenting with syndromic early-onset diabetes. Our review of the clinical manifestations of bi-allelic DNAJC3 mutations (18, $39,40)$ and our new cases confirm the multisystemic nature of the syndrome characterized by diabetes, neurodegenerative manifestations and short stature, and establish hypothyroidism and facial dysmorphism as additional features. The low hair line/microcephaly and skeletal deformities in both patients represent novel characteristics. All DNAJC3 mutations described so far, including the three newly identified, are loss-of-function, either nonsense or affecting the initiation codon, resulting in undetectable DNAJC3 protein (as far as patient cells were available). Consistent with the multisystemic presentation, DNAJC3 is ubiquitously expressed, with high expression in human islets.

The family histories of our patients suggest increased adult-onset diabetes risk in heterozygous DNAJC3 mutation carriers. Kulanuwat et al. reported cosegregation of a low-frequency non-synonymous DNAJC3 variant with early-onset type 2 diabetes in two Thai families with dominant diabetes inheritance (43). Several low-frequency, rare intronic DNAJC3 variants suggest evidence of association $(P<5$ E-04) with diabetes in large-scale GWAS (hg19:chr13:96384253C/T, $\mathrm{MAF}=0.0011, \quad \mathrm{OR}=2.21, \quad P$-value $=0.0004, \quad$ Biobank Japan GWAS; rs9561965, hg19: chr13:96499573A>G,
MAF $=0.098, P$-value $=0.0005$, SIGMA GWAS), and with type 2 diabetes adjusted for BMI in the DIAMANTE meta-analysis (hg19:chr13:96477604G>A, MAF=0.001, $P$-value $=0.0001, \mathrm{OR}=1.97)(41,44)$. These observations support that rare coding and/or regulatory variants near DNAJC3 may increase adult-onset diabetes risk, although additional studies are needed to confirm this.

The phenotype of patients with bi-allelic DNAJC3 mutations overlaps with monogenic diabetes caused by mutations in the PERK-phospho-eIF $2 \alpha$ branch of the ER stress response, characterized by diabetes, neurologic features (microcephaly, intellectual impairment, hearing loss), short stature and bone deformities. Recurrent hypoglycemic episodes observed in patient 1 before diabetes onset were also observed in patients with bi-allelic PPP1R15B mutations, who also had residual insulin secretion (8), and may be due to periods of accrued $\beta$-cell death and insulin 'leakage' into the circulation. PPP1R15B (8) and IER3IP1 (45) mutations increase eIF2 $\alpha$ phosphorylation and ER stress signaling. Mutations in EIF2S3, encoding the $\gamma$ subunit of eIF2, disrupt eIF2 function and also induce ATF4 and CHOP (7). Conversely, Wolcott-Rallison syndrome is caused by EIF2AK3 mutations (6) that reduce PERK-mediated eIF2 $\alpha$ phosphorylation. EIF2B1 mutations, that cause diabetes and liver dysfunction, impair the interaction between P-eIF2 $\alpha$ and eIF2B and may attenuate PERK signaling $(5,46)$. These diseases highlight the crucial role of PERK signaling and regulated protein synthesis to the function of secretory cells, including $\beta$-cells, neurons, chondrocytes and osteoblasts.

Dnajc $3^{-/-}$mice have reduced body weight and develop diabetes at age 4-5 months due to decreased insulin secretion and $\beta$-cell depletion $(16,17)$. The mouse has no neurodegeneration, contrary to DNAJC3-deficient patients (18), but it does have reduced bone size and joint degeneration (47), in line with the patients' skeletal deformities. Ladiges et al. detected $\beta$-cell apoptosis by caspase 3 cleavage in Dnajc $3^{-/}$mouse pancreas (16). We did not observe changes in insulin secretion but found that DNAJC3 deficiency sensitizes rat and human $\beta$-cells to ER stress through Bim-dependent triggering of mitochondrial apoptosis. This is in keeping with the observation that Dnajc $3^{--}$mouse $\beta$-cells have distended ER and mitochondria and susceptibility to ER stress (17). In other monogenic forms of diabetes, loss-of-proteinfunction does not necessarily induce $\beta$-cell dysfunction and death in parallel $(27,48)$.

DNAJC3 protein is upregulated in a mouse model of type 2 diabetes (49) and in islets from type 2 diabetic 
donors (50), suggesting a role in $\beta$-cells in other types of diabetes. DNAJC3 may protect ER stressed cells through regulation of PERK/eIF2 $\alpha$ signaling, but also through PERK-independent mechanisms. DNAJC3 acts as a BiP co-chaperone, promoting its protein processing efficiency $(51,52)$. Supporting the hypothesis that DNAJC3 deficiency affects chaperone function, treatment of Dnajc $3^{-/}$mice with the chemical chaperone PBA improved glucose tolerance (17). Deficiency of DNAJC4, another BiP co-chaperone, also causes constitutive ER stress. Most Dnajc4-deficient mice die perinatally of growth restriction and hypoglycemia, but surviving mice become hypoinsulinemic and glucose intolerant (53). DNAJC3 may also affect ER $\mathrm{Ca}^{2+}$ efflux. The sec61 channel, which mediates protein import into the ER, allows passive $\mathrm{Ca}^{2+}$ efflux. BiP binds sec61, facilitating its closure (54). DNAJC3 depletion increases ER $\mathrm{Ca}^{2+}$ leakage, suggesting that DNAJC3 supports BiP-mediated sec61 gating (54). Early-onset diabetes, sensorineural hearing impairment, cerebellar ataxia, peripheral neuropathy, non-autoimmune hypothyroidism and growth retardation, present in our patients, are also part of the clinical spectrum of Wolfram syndrome $(55,56,57)$. Wolfram syndrome (in its classical form) is caused by autosomal, recessive mutations of WSF1, coding for the ER-localized protein wolframin. Loss of function of wolframin causes dysregulated ER stress, leading to $\beta$-cell apoptosis. Interestingly, the underlying mechanism linking ER stress to $\beta$-cell death in this genetic disorder involves $\mathrm{Ca}^{2+}$ leakage from the ER to the cytosol $(58,59)$, resulting in the hyperactivation of the $\mathrm{Ca}^{2+}$-dependent protease calpain-2 (58). A similar ER $\mathrm{Ca}^{2+}$ leakage-related mechanism may be at play in DNAJC3 diabetes. In keeping with this hypothesis, the apoptotic phenotype of DNAJC3-deficient $\beta$-cells was most obvious upon treatment with the sarco-endoplasmic reticulum $\mathrm{Ca}^{2+}$-ATPase (SERCA) pump inhibitors CPA and thapsigargin, which exacerbate dysregulated $\mathrm{ER} \mathrm{Ca}^{2+}$ homeostasis.

In our rat DNAJC3 deficiency model, Bim activated apoptosis downstream of ER stress. Bim was not transcriptionally induced but it can be activated through posttranslational modifications $(26,60)$. In DNAJC3depeleted human iPSC-derived $\beta$-cells, BIM as well as PUMA mediated ER stress-induced apoptosis. Apoptosis may not be the sole mechanism underlying decreased $\beta$-cell mass in Dnajc $3^{-/}$mice. Models of other ER stressrelated monogenic diabetes, such as Akita (that carry an Ins 2 mutation) and PERK-deficient mice, have defective neonatal $\beta$-cell proliferation $(61,62)$. ER stress halts $\beta$-cell expansion and differentiation in Akita mice and human
Akita iPSC-derived $\beta$-cells, through suppressed AKT/ mTORC1 signaling $(61,63)$.

In conclusion, we describe patients with novel DNAJC3 loss-of-function mutations, causing early-onset diabetes, microcephaly, neurodegenerative features, short stature, bone deformities, hypothyroidism and facial dysmorphism. Bim-dependent mitochondrial $\beta$-cell apoptosis contributes to the pathogenesis of DNAJC3 diabetes, one of five monogenic forms of diabetes pertaining to the PERK pathway of the ER stress response.

\section{Supplementary materials}

This is linked to the online version of the paper at https://doi.org/10.1530/ EJE-20-0636.

\section{Declaration of interest}

The authors declare that there is no conflict of interest that could be perceived as prejudicing the impartiality of this study.

\section{Funding}

This work was funded by the Fonds National de la Recherche Scientifique (FNRS), the Brussels Region Innoviris project DiaType and the Francophone Foundation for Diabetes Research (FFRD, that is sponsored by the French Diabetes Federation, Abbott, Eli Lilly, Merck Sharp \& Dohme and Novo Nordisk) and the Innovative Medicines Initiative 2 Joint Undertaking Rhapsody, under grant agreement No. 115881, supported by the European Union's Horizon 2020 research and innovation program, EFPIA and the Swiss State Secretariat for Education, Research and Innovation (SERI) under contract number 16.0097 to M C; the Agence Nationale pour la Recherche (ANR-09-GENO-021), the European Foundation for the Study of Diabetes/ JDRF/Novo Nordisk, the Assistance Publique-Hôpitaux de Paris Programme Hospitalier de Recherche Clinique (DIAGENE), the Fondation Maladies Rares in the frame of the program 'High throughput sequencing and rare disease' and the ANR-Deutsche Forschungsgemeinschaft (DFG) projet de recherche collaborative international (PRCI) project MONODIA-POP (ANR18-CE92-0031) to C J and by the Fonds Erasme for Medical Research to M L and $\mathrm{M} \mathrm{C}$. The funding agencies were not involved in the design of the study; the collection, analysis and interpretation of the data; writing the report; or the decision to submit the report for publication.

\section{Acknowledgements}

The authors are grateful to the patients and their families for their participation. The authors thank Isabelle Millard, Michael Pangerl, Ying Cai, Antoine Mariscal and Anyishaï Musuaya from the ULB Center for Diabetes Research for excellent technical and experimental support. The authors thank Dr Saddedine for clinical information on one patient. The authors thank the CNRGH for providing access to their genomic platform.

\section{References}

1 Johnson SR, Ellis JJ, Leo PJ, Anderson LK, Ganti U, Harris JE, Curran JA, McInerney-Leo AM, Paramalingam N, Song X et al. Comprehensive genetic screening: the prevalence of maturity-onset diabetes of the young gene variants in a population-based childhood diabetes cohort. Pediatric Diabetes 201920 57-64. (https://doi. org/10.1111/pedi.12766) 
2 Shields BM, Shepherd M, Hudson M, McDonald TJ, Colclough K, Peters J, Knight B, Hyde C, Ellard S, Pearson ER et al. Populationbased assessment of a biomarker-based screening pathway to aid diagnosis of monogenic diabetes in young-onset patients. Diabetes Care 201740 1017-1025. (https://doi.org/10.2337/dc17-0224)

3 Cnop M, Toivonen S, Igoillo-Esteve M \& Salpea PEndoplasmic reticulum stress and eIF $2 \alpha$ phosphorylation: the achilles heel of pancreatic $\beta$ cells. Molecular Metabolism 20176 1024-1039. (https:// doi.org/10.1016/j.molmet.2017.06.001)

4 Cnop M, Foufelle F \& Velloso LA. Endoplasmic reticulum stress, obesity and diabetes. Trends in Molecular Medicine 201218 59-68. (https://doi.org/10.1016/j.molmed.2011.07.010)

5 De Franco E, Caswell R, Johnson MB, Wakeling MN, Zung A, Dung VC, Bich Ngoc CT, Goonetilleke R, Vivanco Jury M, El-Khateeb $\mathrm{M}$ et al. De novo mutations in EIF2B1 affecting eIF2 signaling cause neonatal/early-onset diabetes and transient hepatic dysfunction. Diabetes 202069 477-483. (https://doi.org/10.2337/ db19-1029)

6 Delepine M, Nicolino M, Barrett T, Golamaully M, Lathrop GM \& Julier C. EIF2AK3, encoding translation initiation factor 2- $\alpha$ kinase 3 , is mutated in patients with Wolcott-Rallison syndrome. Nature Genetics 200025 406-409. (https://doi.org/10.1038/78085)

7 Skopkova M, Hennig F, Shin BS, Turner CE, Stanikova D, Brennerova K, Stanik J, Fischer U, Henden L, Muller U et al. EIF2S3 mutations associated with severe X-linked intellectual disability syndrome MEHMO. Human Mutation 201738 409-425. (https://doi. org/10.1002/humu.23170)

8 Abdulkarim B, Nicolino M, Igoillo-Esteve M, Daures M, Romero S, Philippi A, Senee V, Lopes M, Cunha DA, Harding HP et al. A missense mutation in PPP1R15B causes a syndrome including diabetes, short stature, and microcephaly. Diabetes 201564 3951-3962. (https://doi.org/10.2337/db15-0477)

9 Donnelly N, Gorman AM, Gupta S \& Samali A. The eIF2alpha kinases: their structures and functions. Cellular and Molecular Life Sciences 2013 70 3493-3511. (https://doi.org/10.1007/s00018-012-1252-6)

10 Lee TG, Tang N, Thompson S, Miller J \& Katze MG. The 58,000 -dalton cellular inhibitor of the interferon-induced doublestranded RNA-activated protein kinase (PKR) is a member of the tetratricopeptide repeat family of proteins. Molecular and Cellular Biology 199414 2331-2342. (https://doi.org/10.1128/ mcb.14.4.2331)

11 Lee TG, Tomita J, Hovanessian AG \& Katze MG. Purification and partial characterization of a cellular inhibitor of the interferoninduced protein kinase of $\mathrm{Mr} 68,000$ from influenza virus-infected cells. PNAS 199087 6208-6212. (https://doi.org/10.1073/ pnas.87.16.6208)

12 Lee TG, Tomita J, Hovanessian AG \& Katze MG. Characterization and regulation of the 58,000-dalton cellular inhibitor of the interferoninduced, dsRNA-activated protein kinase. Journal of Biological Chemistry 1992267 14238-14243. (https://doi.org/10.1016/S00219258(19)49703-2)

13 van Huizen R, Martindale JL, Gorospe M \& Holbrook NJ. P58IPK, a novel endoplasmic reticulum stress-inducible protein and potential negative regulator of eIF2alpha signaling. Journal of Biological Chemistry 2003278 15558-15564. (https://doi.org/10.1074/jbc. M212074200)

14 Yan W, Frank CL, Korth MJ, Sopher BL, Novoa I, Ron D \& Katze MG. Control of PERK eIF2alpha kinase activity by the endoplasmic reticulum stress-induced molecular chaperone P58IPK. PNAS 200299 15920-15925. (https://doi.org/10.1073/pnas.252341799)

15 Roobol A, Roobol J, Bastide A, Knight JR, Willis AE \& Smales CM. p58IPK is an inhibitor of the eIF2alpha kinase GCN2 and its localization and expression underpin protein synthesis and ER processing capacity. Biochemical Journal 2015465 213-225. (https:// doi.org/10.1042/BJ20140852)
16 Ladiges WC, Knoblaugh SE, Morton JF, Korth MJ, Sopher BL, Baskin CR, MacAuley A, Goodman AG, LeBoeuf RC \& Katze MG. Pancreatic beta-cell failure and diabetes in mice with a deletion mutation of the endoplasmic reticulum molecular chaperone gene P58IPK. Diabetes 200554 1074-1081. (https://doi.org/10.2337/ diabetes.54.4.1074)

17 Han J, Song B, Kim J, Kodali VK, Pottekat A, Wang M, Hassler J, Wang S, Pennathur S, Back SH et al. Antioxidants complement the requirement for protein chaperone function to maintain beta-cell function and glucose homeostasis. Diabetes 201564 2892-2904. (https://doi.org/10.2337/db14-1357)

18 Synofzik M, Haack TB, Kopajtich R, Gorza M, Rapaport D, Greiner M, Schonfeld C, Freiberg C, Schorr S, Holl RW et al. Absence of BiP co-chaperone DNAJC3 causes diabetes mellitus and multisystemic neurodegeneration. American Journal of Human Genetics 201495 689-697. (https://doi.org/10.1016/j.ajhg.2014.10.013)

19 Li H \& Durbin R. Fast and accurate short read alignment with Burrows-Wheeler transform. Bioinformatics 200925 1754-1760. (https://doi.org/10.1093/bioinformatics/btp324)

20 DePristo MA, Banks E, Poplin R, Garimella KV, Maguire JR, Hartl C, Philippakis AA, del Angel G, Rivas MA, Hanna M et al. A framework for variation discovery and genotyping using next-generation DNA sequencing data. Nature Genetics 201143 491-498. (https://doi. org/10.1038/ng.806)

21 Lek M, Karczewski KJ, Minikel EV, Samocha KE, Banks E, Fennell T, O'Donnell-Luria AH, Ware JS, Hill AJ, Cummings BB et al. Analysis of protein-coding genetic variation in 60,706 humans. Nature 2016536 285-291. (https://doi.org/10.1038/nature19057)

22 Scott EM, Halees A, Itan Y, Spencer EG, He Y, Azab MA, Gabriel SB, Belkadi A, Boisson B, Abel L et al. Characterization of Greater Middle Eastern genetic variation for enhanced disease gene discovery. Nature Genetics 201648 1071-1076. (https://doi.org/10.1038/ng.3592)

23 Cunha DA, Hekerman P, Ladrière L, Bazarra-Castro A, Ortis F, Wakeham MC, Moore F, Rasschaert J, Cardozo AK, Bellomo E et al. Initiation and execution of lipotoxic ER stress in pancreatic beta-cells. Journal of Cell Science 2008121 2308-2318. (https://doi. org/10.1242/jcs.026062)

24 Marroqui L, Masini M, Merino B, Grieco FA, Millard I, Dubois C, Quesada I, Marchetti P, Cnop M \& Eizirik DL. Pancreatic $\alpha$ cells are resistant to metabolic stress-induced apoptosis in type 2 diabetes. EBiomedicine 20152 378-385. (https://doi.org/10.1016/j. ebiom.2015.03.012)

25 Marchetti P, Suleiman M \& Marselli L. Organ donor pancreases for the study of human islet cell histology and pathophysiology: a precious and valuable resource. Diabetologia 201861 770-774. (https://doi.org/10.1007/s00125-018-4546-x)

26 Santin I, Moore F, Colli ML, Gurzov EN, Marselli L, Marchetti P \& Eizirik DL. PTPN2, a candidate gene for type 1 diabetes, modulates pancreatic $\beta$-cell apoptosis via regulation of the BH3-only protein Bim. Diabetes 201160 3279-3288. (https://doi.org/10.2337/db11-0758)

27 De Franco E, Lytrivi M, Ibrahim H, Montaser H, Wakeling MN, Fantuzzi F, Patel K, Demarez C, Cai Y, Igoillo-Esteve M et al. YIPF5 mutations cause neonatal diabetes and microcephaly through endoplasmic reticulum stress. Journal of Clinical Investigation 2020 130 6338-6353. (https://doi.org/10.1172/JCI141455)

28 Demine S, Schiavo AA, Marin-Canas S, Marchetti P, Cnop M $\&$ Eizirik DL. Pro-inflammatory cytokines induce cell death, inflammatory responses, and endoplasmic reticulum stress in human iPSC-derived beta cells. Stem Cell Research and Therapy 2020117. (https://doi.org/10.1186/s13287-019-1523-3)

29 Igoillo-Esteve M, Oliveira AF, Cosentino C, Fantuzzi F, Demarez C, Toivonen S, Hu A, Chintawar S, Lopes M, Pachera N et al. Exenatide induces frataxin expression and improves mitochondrial function in Friedreich ataxia. JCI Insight 20205 e134221. (https://doi. org/10.1172/jci.insight.134221) 
30 Cosentino C, Toivonen S, Diaz Villamil E, Atta M, Ravanat JL, Demine S, Schiavo AA, Pachera N, Deglasse JP, Jonas JC et al. Pancreatic $\beta$-cell tRNA hypomethylation and fragmentation link TRMT10A deficiency with diabetes. Nucleic Acids Research 201846 10302-10318. (https://doi.org/10.1093/nar/gky839)

31 Oshima M, Pechberty S, Bellini L, Gopel SO, Campana M, Rouch C, Dairou J, Cosentino C, Fantuzzi F, Toivonen S et al. Stearoyl CoA desaturase is a gatekeeper that protects human beta cells against lipotoxicity and maintains their identity. Diabetologia 202063 395-409. (https://doi.org/10.1007/s00125-019-05046-x)

32 Nair GG, Liu JS, Russ HA, Tran S, Saxton MS, Chen R, Juang C, Li ML, Nguyen VQ, Giacometti S et al. Recapitulating endocrine cell clustering in culture promotes maturation of human stem-cellderived $\beta$ cells. Nature Cell Biology 201921 263-274. (https://doi. org/10.1038/s41556-018-0271-4)

33 Gurzov EN, Germano CM, Cunha DA, Ortis F, Vanderwinden JM, Marchetti P, Zhang L \& Eizirik DL. P53 up-regulated modulator of apoptosis (PUMA) activation contributes to pancreatic $\beta$-cell apoptosis induced by proinflammatory cytokines and endoplasmic reticulum stress. Journal of Biological Chemistry 2010285 19910-19920. (https://doi.org/10.1074/jbc.M110.122374)

34 Cunha DA, Gurzov EN, Naamane N, Ortis F, Cardozo AK, Bugliani M, Marchetti P, Eizirik DL \& Cnop M. JunB protects $\beta$-cells from lipotoxicity via the XBP1-AKT pathway. Cell Death and Differentiation 201421 1313-1324. (https://doi.org/10.1038/cdd.2014.53)

35 Moore F, Naamane N, Colli ML, Bouckenooghe T, Ortis F, Gurzov EN, Igoillo-Esteve M, Mathieu C, Bontempi G, Thykjaer T et al. STAT1 is a master regulator of pancreatic \{beta\}-cell apoptosis and islet inflammation. Journal of Biological Chemistry $2011286929-941$. (https://doi.org/10.1074/jbc.M110.162131)

36 Cnop M, Igoillo-Esteve M, Rai M, Begu A, Serroukh Y, Depondt C, Musuaya AE, Marhfour I, Ladriere L, Moles Lopez X et al. Central role and mechanisms of $\beta$-cell dysfunction and death in Friedreich ataxiaassociated diabetes. Annals of Neurology 201272 971-982.

37 Brozzi F, Gerlo S, Grieco FA, Juusola M, Balhuizen A, Lievens S, Gysemans C, Bugliani M, Mathieu C, Marchetti P et al. Ubiquitin D regulates IRE1alpha/c-Jun N-terminal kinase (JNK) protein-dependent apoptosis in pancreatic beta cells. Journal of Biological Chemistry 2016 291 12040-12056. (https://doi.org/10.1074/jbc.M115.704619)

38 Hoorens A, Van de Casteele M, Klöppel G \& Pipeleers D. Glucose promotes survival of rat pancreatic beta cells by activating synthesis of proteins which suppress a constitutive apoptotic program. Journal of Clinical Investigation 199698 1568-1574. (https://doi.org/10.1172/ JCI118950)

39 Bublitz SK, Alhaddad B, Synofzik M, Kuhl V, Lindner A, Freiberg C, Schmidt H, Strom TM, Haack TB \& Deschauer M. Expanding the phenotype of DNAJC3 mutations: a case with hypothyroidism additionally to diabetes mellitus and multisystemic neurodegeneration. Clinical Genetics 201792 561-562. (https://doi. org/10.1111/cge.13069)

40 Shaheen R, Patel N, Shamseldin H, Alzahrani F, Al-Yamany R, ALMoisheer A, Ewida N, Anazi S, Alnemer M, Elsheikh M et al. Accelerating matchmaking of novel dysmorphology syndromes through clinical and genomic characterization of a large cohort. Genetics in Medicine 201618 686-695.

41 Mahajan A, Taliun D, Thurner M, Robertson NR, Torres JM, Rayner NW, Payne AJ, Steinthorsdottir V, Scott RA, Grarup N et al. Fine-mapping type 2 diabetes loci to single-variant resolution using high-density imputation and islet-specific epigenome maps. Nature Genetics 201850 1505-1513. (https://doi.org/10.1038/s41588-0180241-6)

42 Gurzov EN \& Eizirik DL. Bcl-2 proteins in diabetes: mitochondrial pathways of $\beta$-cell death and dysfunction. Trends in Cell Biology 2011 21 424-431. (https://doi.org/10.1016/j.tcb.2011.03.001)

43 Kulanuwat S, Tangjittipokin W, Jungtrakoon P, Chanprasert C, Sujjitjoon J, Binnima N, Yenchitsomanus PT \& Plengvidhya N.
DNAJC3 mutation in Thai familial type 2 diabetes mellitus. International Journal of Molecular Medicine 201842 1064-1073. (https://doi.org/10.3892/ijmm.2018.3678)

44 Type 2 diabetes knowledge portal. DNAJC3. (available at: http://www. type2diabetesgenetics.org/gene/geneInfo/DNAJC3)

45 Shalev SA, Tenenbaum-Rakover Y, Horovitz Y, Paz VP, Ye H, Carmody D, Highland HM, Boerwinkle E, Hanis CL, Muzny DM et al. Microcephaly, epilepsy, and neonatal diabetes due to compound heterozygous mutations in IER3IP1: insights into the natural history of a rare disorder. Pediatric Diabetes 201415 252-256.

46 Alamri H, Al Mutairi F, Alothman J, Alothaim A, Alfadhel M \& Alfares A. Diabetic ketoacidosis in vanishing white matter. Clinical Case Reports 20164 717-720. (https://doi.org/10.1002/ccr3.597)

47 Gilbert SJ, Meakin LB, Bonnet CS, Nowell MA, Ladiges WC, Morton J, Duance VC \& Mason DJ. Deletion of P58(IPK), the cellular inhibitor of the protein kinases PKR and PERK, causes bone changes and joint degeneration in mice. Frontiers in Endocrinology 20145 174. (https:// doi.org/10.3389/fendo.2014.00174)

48 Igoillo-Esteve M, Genin A, Lambert N, Desir J, Pirson I, Abdulkarim B, Simonis N, Drielsma A, Marselli L, Marchetti P et al. tRNA methyltransferase homolog gene TRMT10A mutation in young onset diabetes and primary microcephaly in humans. PLoS Genetics 20139 e1003888. (https://doi.org/10.1371/journal.pgen.1003888)

49 Lu H, Yang Y, Allister EM, Wijesekara N \& Wheeler MB. The identification of potential factors associated with the development of type 2 diabetes: a quantitative proteomics approach. Molecular and Cellular Proteomics 20087 1434-1451. (https://doi.org/10.1074/mcp. M700478-MCP200)

50 Laybutt DR, Preston AM, Akerfeldt MC, Kench JG, Busch AK, Biankin AV \& Biden TJ. Endoplasmic reticulum stress contributes to beta cell apoptosis in type 2 diabetes. Diabetologia $2007 \mathbf{5 0} 752-763$. (https://doi.org/10.1007/s00125-006-0590-z)

51 Petrova K, Oyadomari S, Hendershot LM \& Ron D. Regulated association of misfolded endoplasmic reticulum lumenal proteins with P58/DNAJc3. EMBO Journal 200827 2862-2872. (https://doi. org/10.1038/emboj.2008.199)

52 Rutkowski DT, Kang SW, Goodman AG, Garrison JL, Taunton J, Katze MG, Kaufman RJ \& Hegde RS. The role of p58IPK in protecting the stressed endoplasmic reticulum. Molecular Biology of the Cell 2007 18 3681-3691. (https://doi.org/10.1091/mbc.e07-03-0272)

53 Fritz JM, Dong M, Apsley KS, Martin EP, Na CL, Sitaraman S $\&$ Weaver TE. Deficiency of the BiP cochaperone ERdj4 causes constitutive endoplasmic reticulum stress and metabolic defects. Molecular Biology of the Cell 201425 431-440. (https://doi. org/10.1091/mbc.E13-06-0319)

54 Schorr S, Klein MC, Gamayun I, Melnyk A, Jung M, Schauble N, Wang Q, Hemmis B, Bochen F, Greiner M et al. Co-chaperone specificity in gating of the polypeptide conducting channel in the membrane of the human endoplasmic reticulum. Journal of Biological Chemistry 2015290 18621-18635. (https://doi.org/10.1074/jbc. M115.636639)

55 Urano F. Wolfram syndrome: diagnosis, management, and treatment. Current Diabetes Reports 201616 6. (https://doi.org/10.1007/s11892015-0702-6)

56 Barrett TG, Bundey SE \& Macleod AF. Neurodegeneration and diabetes: UK Nationwide Study of Wolfram (DIDMOAD) syndrome. Lancet 1995346 1458-1463. (https://doi.org/10.1016/s01406736(95)92473-6)

57 Wolfram Syndrome Guideline Development Group. Management of Wolfram syndrome: a clinical guideline, 2014. (available at: http:// www.orpha.net/national/data/IE-EN/www/uploads/Wolfram2014.pdf)

58 Lu S, Kanekura K, Hara T, Mahadevan J, Spears LD, Oslowski CM, Martinez R, Yamazaki-Inoue M, Toyoda M, Neilson A et al. A calciumdependent protease as a potential therapeutic target for Wolfram syndrome. PNAS 2014111 E5292-E5301. (https://doi.org/10.1073/ pnas.1421055111) 
59 Takei D, Ishihara H, Yamaguchi S, Yamada T, Tamura A, Katagiri H, Maruyama Y \& Oka Y WFS1 protein modulates the free $\mathrm{Ca}(2+)$ concentration in the endoplasmic reticulum. FEBS Letters $2006 \mathbf{5 8 0}$ 5635-5640. (https://doi.org/10.1016/j.febslet.2006.09.007)

60 Puthalakath H, O'Reilly LA, Gunn P, Lee L, Kelly PN, Huntington ND, Hughes PD, Michalak EM, McKimm-Breschkin J, Motoyama N et al. ER stress triggers apoptosis by activating BH3-only protein Bim. Cell 2007129 1337-1349. (https://doi.org/10.1016/j.cell.2007.04.027)

61 Riahi Y, Israeli T, Yeroslaviz R, Chimenez S, Avrahami D, StolovichRain M, Alter I, Sebag M, Polin N, Bernal-Mizrachi E et al. Inhibition of mTORC1 by ER stress impairs neonatal beta-cell expansion and predisposes to diabetes in the Akita mouse. eLife 20187 e38472. (https://doi.org/10.7554/eLife.38472)

62 Zhang W, Feng D, Li Y, Iida K, McGrath B, Cavener DR. PERK EIF2AK3 control of pancreatic beta cell differentiation and proliferation is required for postnatal glucose homeostasis. Cell Metabolism 20064 491-497. (https://doi.org/10.1016/j.cmet.2006.11.002)

63 Balboa D, Saarimaki-Vire J, Borshagovski D, Survila M, Lindholm P, Galli E, Eurola S, Ustinov J, Grym H, Huopio H et al. Insulin mutations impair beta-cell development in a patient-derived iPSC model of neonatal diabetes. eLife 20187 e38519. (https://doi. org/10.7554/eLife.38519)

64 GTEx Consortium. The genotype-tissue expression (GTEx) project. Nature Genetics 201345 580-585. (https://doi.org/10.1038/ng.2653)

65 Eizirik DL, Sammeth M, Bouckenooghe T, Bottu G, Sisino G, IgoilloEsteve M, Ortis F, Santin I, Colli ML, Barthson J et al. The human pancreatic islet transcriptome: expression of candidate genes for type 1 diabetes and the impact of pro-inflammatory cytokines. PLoS Genetics 20128 e1002552. (https://doi.org/10.1371/journal. pgen.1002552)

66 Cnop M, Abdulkarim B, Bottu G, Cunha DA, Igoillo-Esteve M, Masini M, Turatsinze JV, Griebel T, Villate O, Santin I et al. RNA sequencing identifies dysregulation of the human pancreatic islet transcriptome by the saturated fatty acid palmitate. Diabetes $2014 \mathbf{6 3}$ 1978-1993. (https://doi.org/10.2337/db13-1383)

67 Moriarity BS, Otto GM, Rahrmann EP, Rathe SK, Wolf NK, Weg MT, Manlove LA, LaRue RS, Temiz NA, Molyneux SD et al. A sleeping beauty forward genetic screen identifies new genes and pathways driving osteosarcoma development and metastasis. Nature Genetics 201547 615-624. (https://doi.org/10.1038/ng.3293)

Received 8 June 2020

Revised version received 11 December 2020

Accepted 22 January 2021 